\title{
A Critical Shortage in U.S. Agricultural Research Funding: A Time for Action
}

\author{
Noel T. Keen and Jacqueline Fletcher
}

Noel Keen, President of The American Phytopathological Society, 2001-2002, passed away on April 18, 2002.

Many APS members knew Noel Keen as a remarkably productive and innovative scientist, which of course he was. But in recent years, based on his accumulated experience with funding opportunities and limitations within the United States, and with his many international connections, Noel became frustrated with the level of funding for agricultural research in our nation compared with that provided for other research areas such as medicine and defense. The word he liked to use to describe this support level was "anemic." Noel decided to try to do something about it, and this effort became a passion for him. He served on a National Research Council committee studying the U.S. Department of Agriculture's National Research Initiative (NRI), which he believed should be the "NIH for agricultural research."

Increasing competitive agricultural funding in the United States became a campaign issue for Noel when he decided to run for the office of APS president in 1999. In the May 1999 issue of Phytopathology News, Noel's campaign address included the following comments: "I do see APS as a vehicle for improving the common good of plant pathologists and other agricultural scientists in the U.S., namely to facilitate increased competitive public funding for agricultural research-agricultural scientists in general and scientific societies in particular need to accelerate efforts to identify for Congress the value of increasing the NRI budget.... My major 'campaign plank' is therefore to increase efforts to inform legislators of the value of the NRI and enlist the support of major agricultural industry leaders, commodity groups, and other interested parties in arguing for budget increases.... The APS vice presidency and presidency are excellent vehicles from which to launch such an effort... In a pro-science era when the NSF budget sits at \$4 billion and the NIH budget exceeds \$14 billion, it is a national disgrace that the NRI budget hovers at the $\$ 120$ million annual level. Let's change that."

Noel initiated his funding efforts while serving as APS Vice President and President-Elect, and continued his work in his presidency, visiting in Washington D.C. with individuals who play key roles in funding initiatives within the USDA and the National Science Foundation (NSF) and with members of Congress. He began to develop this Plenary Session early during his presidency and worked on it until shortly before his death, continuing to believe in its value and potential for triggering change. Last spring, when he realized he would not be able to speak to you today himself, he sent me notes of the thoughts and ideas he wanted to share with you, so many of my comments this morning come directly from Noel. He envisioned the session concluding with lively discussion and the emergence of a plan for action.

Publication no. P-2002-1107-010

\section{SOME FACTS AND OBSERVATIONS}

- In 2000, \$25 billion was spent on direct grower subsidies in the United States. In the same year, $23 \%$ of rural children lived in poverty (Newsweek, 10 September 2001).

- From 1982 to 1998 , the food/agriculture research share of the federal total fell from 4.2 to $2.5 \%$, contrasting with a $16 \%$ share of U.S. income/employment by this sector (NSF data).

- Recruitment of top U.S. students into the agricultural sciences is becoming more and more difficult. Those in academia have experienced this firsthand as our classes shrink and we must step up our efforts to attract bright and qualified graduate students.

- U.S. commodity prices at the farm gate are low.

- Drug/pharmaceutical costs continue to increase sharply in the United States.

Problems we face. Problems involving agriculture and the environment continue to mount. We read about the consequences, real and anticipated, of waste disposal from intensive animal production facilities, salinization of arable soils, loss of prime agricultural lands to urban development, potential bio-terrorist attacks on the food supply, loss of wildlife habitats, and many other issues.

So, what is the funding situation? Recent annual increases in the NIH budget dwarf the entire USDA research budget (President Bush's budget recommended a $\$ 5.5$ billion increase for $\mathrm{NIH}$ in 2003). In 2000, the USDA/NRI budget was $\$ 109$ million, while the NIH budget was in excess of $\$ 17$ billion. The NRI allocation was $\$ 120$ million for 2002 and $\$ 130$ million for 2003 (the requested amount was $\$ 240$ million for 2003). In contrast, the NIH allocation was \$23.7 billion for 2002 and \$27.5 billion for 2003 . Secretary of Agriculture Joseph Jen has set a goal to bring the NRI budget to its congressionally authorized, but not appropriated, level of $\$ 500$ million per year.

What do these problems all have in common? Lack of adequate federal competitively allocated research funds to support agricultural research. Noel wanted me to make the case that improved federal funding for agricultural research, across the board, but especially competitively allocated funds, would do much to harness the power of the U.S. scientific community to address the issues mentioned above. He proposed that more competitively allocated research funds would (i) develop higher value/value-added crops (e.g., vaccines, pharmaceutical proteins produced in crop plants, use of engineered plants for production of plastics, and renewable energy sources, etc.) - all of these benefits would lead to the inescapable consequence of increasing farm income; (ii) increase agricultural productivity-the judicious use of transgenic technologies will revolutionize American agriculture and dramatically increase plant and animal productivity through more productivity per acre of cropland or feedlot; (iii) greatly 
reduce the negative environmental impacts of agriculture such as feedlot waste problems and fertilizer runoff into watersheds - the use of plants and animals genetically engineered to be more productive and efficient will reduce the square acreage of land needed for agriculture, and plants modified to resist adverse conditions will permit use of marginal (e.g., saline) lands for agricultural production; and (iv) provide critically needed support for preventing, detecting, and responding to microbial agents of bio-terrorism or bio-warfare targeted toward U.S. crops or livestock.

In each of these examples, increased research funding would do much to harness and extend the power of the U.S. scientific community. The advances would benefit the whole of American agriculture, including both small and large growers. It would promote our agricultural exports, reduce dependency on agricultural subsidies, and greatly increase the overall health of the U.S. agricultural enterprise.

However, part of the responsibility for the inadequacy of U.S. agricultural research funding rests upon groups other than the funding agencies. Agricultural advocacy groups, commodity groups, industries, and professional societies all have a voice. Unfortunately, however, if these groups speak with different voices and identify different priority issues, the message that reaches the ears of policy makers will not be clear. This lack of unification has certainly contributed to erosion of federal funding for agricultural research in recent years, because Congress has received incon- sistent communications from the agricultural community and its advocates. Agricultural groups must first communicate with one another, develop a uniform plan, and deliver the message clearly. Working together will not dilute our efforts. The point cannot be emphasized enough that increased federal agricultural research funding will benefit ALL constituent groups.

\section{CONCLUSION}

The problems that face American production agriculture have never been more challenging. The concerns mentioned above have accumulated and expanded during a decade in which federal funding for agricultural research has been essentially flat. Indeed, recent annual increases for the NIH budget have far exceeded total federal allocations for agricultural research. Rural poverty remains at $25 \%$ or higher and federal cash subsidies for growers remain high, again exceeding the annual expenditure on agricultural research. Agricultural research scientists are frustrated and the number of bright young U.S. scientists entering our graduate programs, and ultimately the agricultural research field, is declining. Increases in federal funding for agricultural research, especially competitively allocated funds, would go far toward solving many problems confronted by the American agricultural enterprise. As individuals, as institutions, as professional societies-clearly, it is time to take action! 